\title{
"CLIQUES": ACADEMIC RELATIONSHIPS AMONG HIGHER EDUCATION STUDENTS
}

\section{AS “PANELAS”: RELACIONAMENTOS ACADEMICOS DE ALUNOS DE ENSINO SUPERIOR}

Recebido em 25.11.2020 Aprovado em 25.04.2021

Avaliado pelo sistema double blind review

Geraldo Magela Rodrigues de Vasconcelos

DOI: https://doi.org/10.12712/rpca.v15i1.47335

gmrv@ufsj.edu.br

Departamento de Ciências Administrativas e Contábeis - Universidade Federal de São del-Rei - São João del-Rei-MG-Brasil

https://orcid.org/0000-0002-7562-3638

\section{Ester Sarah Liandro}

esterliandro@gmail.com

Universidade Federal de São del-Rei - São João del-Rei-MG-Brasil

https://orcid.org/0000-0003-0325-2206

\section{Velcimiro Inácio Maia}

maia@ufsi.edu.br

DTECH- Departamento de Tecnologia e Humanidades - Universidade Federal de São del-Rei - São João del-Rei-MG-Brasil

https://orcid.org/0000-0003-1283-6529

\section{Gustavo Melo Silva}

gustavomelo@ufsj.edu.br

Departamento de Ciências Administrativas e Contábeis - Universidade Federal de São del-Rei - São João del-Rei-MG-Brasil

https://orcid.org/0000-0001-6431-1594

\begin{abstract}
This work has investigated the academic relationships of five classes, 185 students, from an Undergraduate Business Administration course, on-site. The Social Network Analysis (SNA) research technique has been used. The results show that homophilia is predominant in the formation of groups. Only in one class does performance have a greater influence. The "cliques" were more clearly defined in only one class. The analysis of the results also indicates that students with social brokerage roles perform better than their peers.
\end{abstract}

Keywords: Higher education student; Social network analysis; Academic achievement; Academic relationships.

\section{Resumo}

Este trabalho investigou os relacionamentos acadêmicos de cinco turmas, 185 alunos, de um curso de Graduação em Administração, modalidade presencial. Utilizou-se da técnica de pesquisa Análise de Redes Sociais - ARS. Os resultados mostram que a homofilia é preponderante na formação de grupos. Apenas em uma turma o desempenho exerce maior influência. As "panelas" se mostraram mais notadamente definidas em apenas uma turma. A análise dos resultados indica, ainda, que alunos com papéis sociais de brokerage possuem desempenho superior ao de seus pares.

Palavras-chave: Estudante universitário; Análise de redes sociais; Desempenho acadêmico; Relacionamentos acadêmicos 


\section{Introduction}

The analysis of student relationships in schools dates back to at least 1944, with research published by Smith (1944), who analyzed the quantity and quality of relationships and the cohesion of groups of students. For this study, Smith (1944) used sociometry as a research method, within the scope of Social Network Analysis (SNA, from here on). In the Coleman Report (Coleman et al., 1966), as it is called, there is mention of the effect of the average academic performance of schoolmates on individual academic performance as well, which may denote that the relationships developed can influence the latter.

The classroom can shape the integration of students into the academic world, including their persistence in continuing the course (Tinto, 1975, 1997). For this author, the classroom is where the student and the university meet, as well as the social and the academy, and where the student's involvement and/or integration occurs. It is in this space that participation in collaborative work allows the student to develop a support network. And yet, at first, it is in this space that the student's attention turns to making social connections with his or her colleagues.

As previously mentioned, SNA has been used in teaching research since 1944. And its adoption has been suggested as necessary for the analysis of social interactions in the school environment and for relating them to performance, for example (Lomi, Snijders, Steglich , \& Torló, 2011).

SNA represents an approach that provides a greater understanding of the types of relationships that are developed among students and the results of those relationships in terms of commitment and persistence in remaining in the course (Scott, 2000).

Taking this perspective into account, the research question to be analyzed on this paper is "What are the characteristics of the relationship network of students of the Undergraduate Course in Administration at UFSJ?". In order to answer this guiding question, the use of SNA is proposed, as will be detailed in the Research Method section.

In order to answer the guiding question of the research, the objective of this work is to investigate the characteristics of the social relationship networks that are established in the classroom. To attain this objective, SNA has been used, as mentioned. In addition, the degree of cohesion of the class and the subgroups that are formed has been analyzed by examining the formation of "cliques", the characteristics (attributes) of the students (ethnicity, age, gender etc.) and by assessing the homophilia and heterophilia, through the association of these attributes with networks and subgroups.

Furthermore, this study is preliminary. There is a scarcity of publications in this line of research in Brazil, at least as far as the authors of this work are aware. Few articles published in Brazil have been found that specifically use SNA to analyze the interaction of students in the classroom (see, for example, Carbonai, 2017; Carbonai \& Colvero, 2014; Leonardo, Farina, Andreoli, \& Lima, 2019 ; Andreoli, Leonardo, Farina, \& Lima, 2019). It should be noted that two of these studies analyze relationships in high school and one of them was carried out in an Italian school. Two others are related to higher education students. Furthermore, the effects of social networks on the formation of student networks in the academic world have been little explored in research in education and in the SNA (Palacios \& Villalobos, 2016).

This work can contribute to SNA literature and teaching, by presenting the use of social networks to understand the relationships that are established in university education. It seems to be a promising area of research in Brazil, both for SNA and for teaching, as it already occurs in other countries. 
In addition to this introduction, this work is structured in four sections. Section two presents the theoretical framework of the research. In order to do so, we tried to present the state of the art of research in education using SNA. After that, the research method used and the data collection and analysis procedures are presented. The following section presents the results of the survey. Then, section five, discussions and closing remarks.

\section{Theoretical frame of reference}

The entrance of young people and young adults in a Higher Education Institution (HEI) represents a challenge for this public, as a new socialization will be necessary, both with regard to the HEI, with its norms and symbolic values, and in relation to new peers. It will take an affiliation process (Coulon, 2017) and the development of quick responses to the challenges and symbolic demands presented to students by the courses they have chosen (Portes, 2014).

This affiliation process can be driven by new relationships, or even "friendships", that are formed within the university (Carneiro, 2010; Sampaio \& Santos, 2015). It has also been argued that these social interactions and networks of relationships established at the university play an important role in the affiliation process (Coulon, 2008), as they provide students with the possibility of facing academic, relational and normative difficulties in the university environment (Sampaio \& Santos, 2015). These authors seem to suggest, as well as Carneiro (2010), that networks, with their role in the affiliation process, can contribute to reducing evasion. Or, as Carneiro (2010) proposes, there is a positive association among the support networks for the permanence of students in the HEI. In addition, in the case of adolescents, the student network in a classroom can influence the progress of the classroom, constraining inappropriate behaviors and influencing the performance and school involvement of the class (Palacios et al., 2019).

It is also stated that affective relationships and support networks, with exchange of information between peers at the university, accelerate the affiliation process, according to Coulon (2008), with the student being more prepared for life in higher education (Carneiro, 2010). This author even associates the support networks for the permanence of students in the HEI.

There is evidence that the integration process begins in the first weeks of class, with students forming bonds with other students and recognizing their importance for university life (Teixeira, Castro, \& Zoltowski, 2012; Santos, Oliveira , \& Dias, 2015).

In the process of developing new relationships, there is a dynamic of social selection (Fortuin, Geel, \& Vedder, 2016; de Klepper, Sleebos, van de Bunt, \& Agneessens, 2010), in which students find themselves exposed to unknown people most of the time, and there is a pursuit, as mentioned (Tinto, 1975), for the formation of social bonds. Thus, entering the university causes transformations in friendship and in the support that students receive (Teixeira, Dias, Wottrich, \& Oliveira, 2008).

As previously mentioned, SNA has been used in research in the field of education since 1944. And its adoption has been suggested as necessary for the analysis of social interactions in the school environment and for relating them to performance, for example (Lomi et al., 2011).

SNA has investigated, specifically in the area of education, various themes, such as relations between students and crimes committed (Snijders \& Baerveldt, 2003); ethnicity (Fortuin et al., 2016); causes of similarity between friends in the classroom (de Klepper et al., 2010); relationship between networks and student performance (Carbonai, 2017; Lomi et al., 2011), among others, as shown below.

The most used SNA measures are centrality, intermediation, intra- and intergroup analysis, homophily and heterophilia, indegree and outdegree (Carbonai, 2017). For example, it is asserted 
to analyze correlations between the actors' position in the network, especially centrality, and their academic performance (Saxena, Reddy, Saxena, \& Gera, 2019). There is evidence, at least in high school, that centrality (eigenvector), proximity, degree and intermediation are associated with performance (Ortiz, Hoyos, \& López, 2004). In addition to the correlation between the metrics of the networks with academic performance, students with superior performance are in central positions in the network (Z. Liu, Kang, Su, S. Liu, \& Sun, 2020).

SNA was also used to analyze the sense of community perceived by students in higher education (Dawson, 2008). The findings indicate that the position the individual occupies in the network indicates the perceived sense of community and the type of support - academic and social - that the student needs for his or her progression in the course. In this study, measures of degree centrality and intermediation and proximity were used. The results suggested that the position that the student occupies in the network indicates the degree of sense of community that the actor perceives. In the case of online training programs (distance learning - DL), it was also found that student interactions, even online, are important for the effectiveness of learning (Fantinelli \& Russo, 2018). Still considering the student's structural position in the network, Scott (2000) found that this position has an influence on the satisfaction, performance and persistence of this student.

Gender similarity has been fundamental to the formation of study relationships between students, being a relevant variable in this formation (Palacios \& Villalobos, 2016; Palacios \& Berger, 2015; Burk, Steglich \& Snijders, 2007), as well as students of the same skin color (Shin \& Ryan, 2014), but not of the same age (Burk, Steglich, \& Snijders, 2007).

Relationships with classmates, and also with teachers, have been the object of analysis in relation to the emotional support offered, which can lead other peers to pursue academic goals, facilitating social and academic adjustment (Wentzel, Battle, Russell, \& Looney, 2010). These relationships even contribute to sustaining the student's intellectual affiliation throughout his or her academic life (Carneiro, 2010).

In fact, relationships, by allowing students to formulate thoughts and arguments with their peers, have an impact on learning, in addition to building personal and ethical relationships (Gibson, 2003).

In the case of ascertaining the impact of networks, it is believed that a student's performance is similar to that of their "friends", and that students who have similar performances are more likely to form groups (Lomi et al., 2011). Also, that students tend to obtain the average performance of classmates with whom they relate and, tend to form bonds of friendship as well. In addition, in this study, it was observed that "popularity" of students does not affect their performance. Furthermore, students with low performance are more likely to choose other students with low performance as friends. And yet, the attraction to peers is partly driven by academic performance with high-performing students, who receive more referrals from friends over time than lowperforming students. (Gremmen, Dijkstra, Steglich, \& Veenstra, 2017).

In the case of primary school students, students nominated as friends perform better than other students (Palacios \& Berger, 2015). Fortuin et al. (2016) analyzed the influence of classmates on each other's academic performance. In addition, they investigated whether the selection of their classmates to work together in the classroom is based on the performance of other colleagues. It was concluded that such selection is not based on the academic performance of these peers, but that the student's performance, in its turn, is influenced by the performance of his or her peers. Another analysis considered the influence of roommates, who are chosen by the institution at random. With this procedure, the author canceled the effect of selection and influence of peers in the classroom. And he found that roommates positively influence each other's performance (Priest, 2001). Students are also influenced by colleagues who sit next to them (Hong \& Lee, 2017) 
However, for other authors, similar academic performance is a predictor of friendship bonds (Flashman, 2012) and performance promotes the selection of those with whom to form friendship bonds (Lomi et al., 2011). It is also claimed that the homophily, mentioned above, is the result of selection (Smirnov \& Thurner, 2016).

This influence can be negative or positive on the student's performance, and more, over time, grades tend to become similar (Fortuin et al., 2016).

It is also argued that, when considering the subgroups that are formed in the by the students in an academic network, they are homogeneous, which means that there is a homophilic selection (people's tendency to choose people who are similar to themselves as mates/friends) (Carbonai, 2017), being responsible for that homogeneity (Cohen, 1977).

\section{Research method}

The research method for carrying out this work was the quantitative analysis, using the SNA. For this analysis, the UCINET 6.0 software (Borgatti, Everett, \& Freeman, 2002), Gephi 0.9.2 (Bastian, Heymann, \& Jacomy, 2009) and the Statnet package on the R platform (Handcock, Hunter, Butts, Goodreau, \& Morris, 2003) were used. These software packages, widely used by SNA researchers, allow not only the analysis of network variables, but also the graphic representation, through sociograms, of cooperation networks.

The research involved students from five classes of the Administration course at the Federal University of São João del-Rei - UFSJ, studying Full time or on the night shift. 36 from the 3rd full-time term, 40 from the 3rd night term, 30 from the 6th ful-time term, 38 from the 6th night term and 41 from the 8th night term. The choice of these terms was due to the exposure to the course that the students had already had during the first periods; and the period of data collection that was carried out during the two academic semesters of 2019. This choice is similar to that adopted by Rovai (2002). The Course chosen to carry out the research was defined by the convenience criterion, since the research coordinator taught in the defined course.

As the classes of each discipline are made up of new students in several years ("irregular" students), and there are students enrolled in the researched classes who, by chance, failed in some prerequisite discipline for another, it was decided to carry out data collection in subjects in which there were the largest number of Business Administration students entering the regular year. This decision was based on Burke and Sass (2008) cited by Lomi et al. (2011) who argue that the effect of peers is best analyzed at the classroom level.

For data collection, a questionnaire was prepared for each discipline, which contained questions related to the characteristics of each student, such as: city of residence, skin color, Income Coefficient, gender, age, family income, type of residence, professional record (whether they work and study or only study). These attributes were used to characterize the members of the network and of the subgroups that are formed in the classroom.

Subsequently, at the beginning of the following semester, through consultation with the Academic Control System of the Federal University of São João del-Rei (CONTAC) the performance coefficients (PC) of each student were obtained, completing the characterization of the students. This procedure is similar to that adopted by Gobithaasan, Din, Amachandran and Hasni (2019). It should also be noted that for Palacios and Villalobos (2016) academic performance is an important variable to understand the structure of the networks that are formed. The use of PC is based on Carbonai (2017) and Lomi et al. (2011). For this analysis, these authors used students' grades in certain subjects or assessments that are regularly carried out. 
Still composing the research questionnaire, participating students were asked to inform which students they are academically related to, with whom they develop activities in the classroom and outside class, indicating, on the list of students enrolled in the discipline, their favorite colleagues to study and carry out work, both in the classroom and in out-of-class activities.

Several research publications use the expression "friends" in this question. In this project, it was decided not to use the expression "friends" and "friendship", as its definition is imprecise. There are varying degrees of friendship and ambiguity in their conceptualization, as they depend on social class, age and gender (van de Bunt, van Duijn, \& Snijders, 1999). Thus, the expression "mates" was used, which are the preferred students for carrying out work, both in the classroom and out of class. This decision was made despite evidence that the networks of academic and friendship relationships may be similar (Palacios et al., 2019). As academic relationships often occur outside of school, for example, preparing assignments, preparing seminars or studying for exams (Palacios et al., 2019) it was decided to insert a question in the questionnaire that covered these activities, in addition to those carried out in the classroom - " ... which are the preferred classmates with whom you carry out academic activities (group work, seminars etc.), both in the classroom and in extraclass activities (preparing seminars/presentations, studying etc.)". However, it can be considered that the classroom is the main setting for social interaction, generating the creation of networks within the classroom in some academic systems, mainly in the traditional system in which they have classroom lessons on a daily basis (Gremmen et al., 2017 ).

Visits were made to the classes of the selected disciplines, under authorization from the teachers, to present the research objectives, communicate about the data collection procedures, and request to answer the questionnaire distributed to the class.

The questionnaires were applied in the first semester of 2019 in the subjects of Financial Mathematics (full time) and General Theory of Administration (night shift), both in the third term. It was observed that in the Financial Mathematics class there were 46 students enrolled, as well as in that of General Theory of Administration, of which, 36 respondent students, eight dropouts and one non-participant in the Financial Mathematics discipline; and 40 respondents in General Administration Theory, five dropouts and one student with justification for maternity leave.

The selection of the other three classes, in the second semester of 2019, started with the same method used in the previous classes, that is, by analyzing the number of students enrolled in the disciplines of the semester, seeking those with the largest sample, with the smallest number of dropouts or irregular students. The selected subjects were: Marketing II (6th full time term), Small Business Management (8th night term), People Management II (6th night term). In the Marketing II and People Management II disciplines, all enrolled students responded to the questionnaire, with a total of 68 students, 30 students from the Marketing II discipline and 38 students from the People Management II discipline. The total number of questionnaires not applied in this stage was five, all of which were in the Small Business Management discipline, due to student dropout. 
Table 1 shows students enrolled and respondents in the classes surveyed.

Table 1 - Classes surveyed

\begin{tabular}{|c|c|c|c|c|c|c|c|}
\hline Data collect & Classes & Subjects & $\begin{array}{l}\text { Enrolled } \\
\text { students }\end{array}$ & $\begin{array}{c}\text { Respon- } \\
\text { dent }\end{array}$ & $\begin{array}{c}\text { Drop- } \\
\text { out }^{1}\end{array}$ & Other $^{2}$ & Other ${ }^{3}$ \\
\hline \multirow{2}{*}{$\begin{array}{l}\text { 1st Term of } \\
2019\end{array}$} & $\begin{array}{l}\text { 3rd full- } \\
\text { time term }\end{array}$ & Financial Math & 46 & 36 & 8 & 0 & 2 \\
\hline & $\begin{array}{l}\text { 3rd night } \\
\text { term }\end{array}$ & $\begin{array}{l}\text { General Theory of } \\
\text { administration }\end{array}$ & 46 & 40 & 5 & 1 & 0 \\
\hline \multirow{3}{*}{$\begin{array}{l}\text { 2nd Term } \\
\text { of } 2019\end{array}$} & $\begin{array}{l}\text { 6th full- } \\
\text { time term }\end{array}$ & Marketing II & 30 & 30 & 0 & 0 & 0 \\
\hline & $\begin{array}{l}\text { 6th night } \\
\text { term }\end{array}$ & $\begin{array}{l}\text { People } \\
\text { Management II }\end{array}$ & 38 & 38 & 0 & 0 & 0 \\
\hline & $\begin{array}{l}\text { 8th nigth } \\
\text { term }\end{array}$ & $\begin{array}{l}\text { Small Business } \\
\text { Management }\end{array}$ & 46 & 41 & 5 & 0 & 0 \\
\hline TOTAL & -- & -- & 206 & 185 & 18 & 1 & 2 \\
\hline
\end{tabular}

1 - Withdrawn from taking the course

2 - Maternity leave

3- Did not participate in the Research

Source: Research data

The analysis was developed through the relation between the data provided by the students on the questionnaires applied and their positions as members of the relationship networks. The main question was to observe if any attribute influences the formation of "cliques" in the classroom, as for example, if the gender attribute would be a crucial characteristic for the emergence of connections in the academic environment.

Thus, we seek to analyze through the ERGM (Exponential Random Graph Models) the network of ties between students. For this, two questions were posed: (1) What is the typical propensity of students to establish relationships with each other, regardless of personal attributes? (2) What is the influence of personal attributes on your propensity to establish bonds?

For analyses using ERGM, the researcher must define one or more terms that express possible generating characteristics of the network. The terms are inserted in a formula in the modeling software package, so it is possible to estimate the most appropriate parameters for each term, aiming to define with a greater or lesser degree of reliability the individualized contribution of each term to the generation of a set of graphs that have structural characteristics similar to those of the empirically obtained network (Fernandes, Maranhão, De Andrade, \& Sampaio, 2017).

In this study, we used the Statnet package on the R platform to do the ERGM modeling. To answer the first question asked, we use the term "edges", which allows the exploration of the structural aspect related to the ability of the nodes to weave ties with each other. For the second question, we use the term nodematch (attrname) to estimate the probability of establishing ties between two nodes based on the similarity of an attribute of these nodes. We have inserted the attributes of the students used in the research into the model.

\section{Results}

From the data collected, it was possible to build the networks of each class and identify the formation of subgroups, as can be seen in Figure 1. 

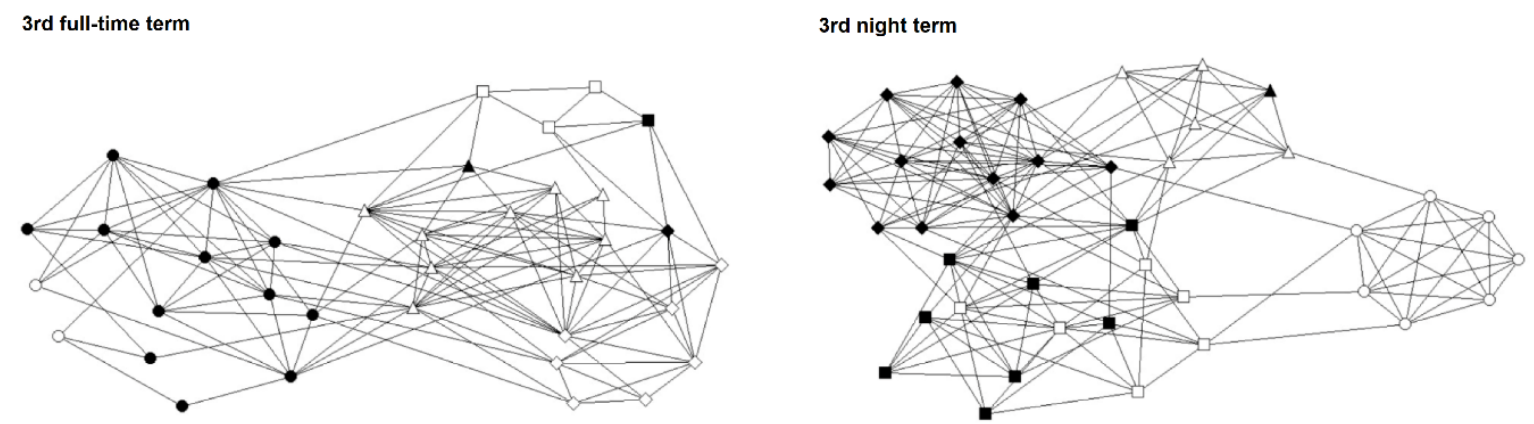

6th full-time term

6th night term
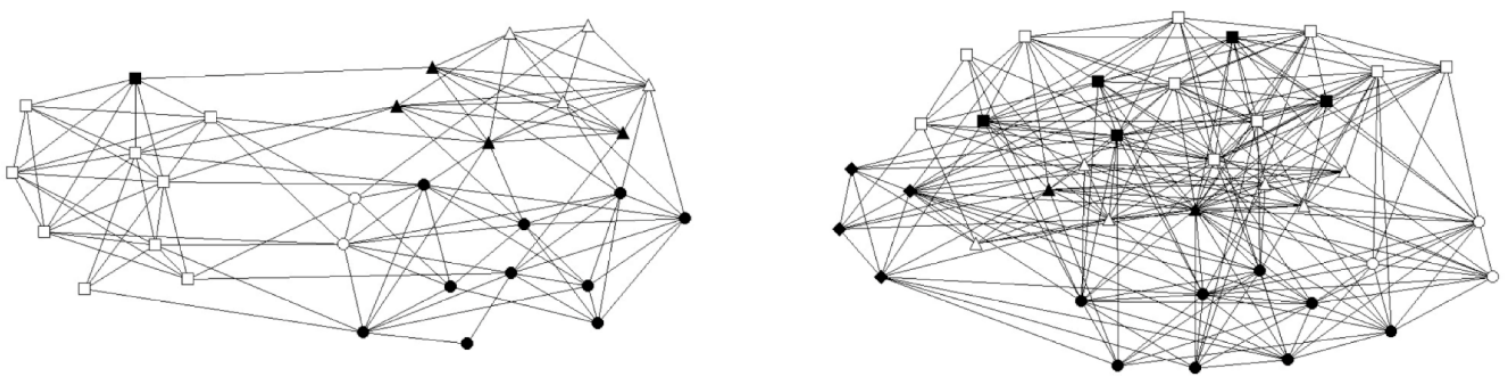

8th night term
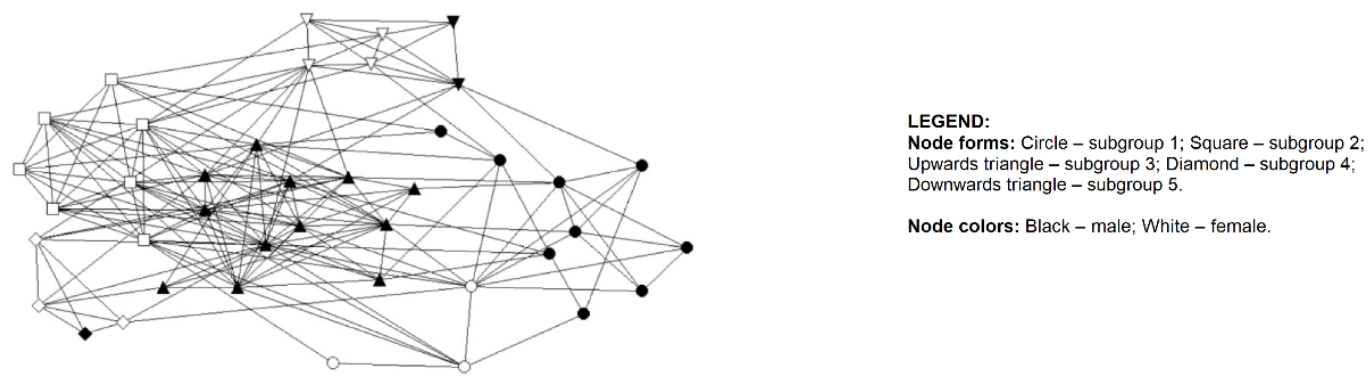

Upwards triangle - subgroup 3; Diamond - subgroup 4; Downwards triangle - subgroup 5 .

Node colors: Black - male; White - female.

Figure 1 - Relationship networks in academic activities

Source: Research Data

\section{Network description}

From the data collected, it was possible to identify the structure of relationships in the classes of the undergraduate course in administration, through sociograms of the 5 classes (Figure 1). The networks identified per class indicate a dynamic of social selection (Fortuin et al., 2016; de Klepper et al., 2010) with a pursuit for the formation of social bonds (Tinto, 1975). These networks seem to point to a sense of community perceived by higher education students (Dawson, 2008), in which social relationships can promote emotional support by facilitating social and academic adjustment (Wentzel et al., 2010). Confirming Tinto's studies $(1975,1977)$, networks of the classes indicate that in the classroom and in academic work, students promoted the development of a support network through social connections with their peers. These, according to Coulon (2017), used social networks to deal with the challenges of the academic world through a new socialization with affiliation based on attributes existing in social groups that became part of the respective classes of the course periods analyzed.

In order to characterize the networks of each class, we selected the most common SNA metrics, which are listed in Table 2. 
Table 2 - Descriptive statistics on the structure of student networks

\begin{tabular}{lccccc}
\hline Description & $\begin{array}{c}\text { 3rd full- } \\
\text { time term }\end{array}$ & $\begin{array}{c}\text { 3rd night } \\
\text { term }\end{array}$ & $\begin{array}{c}\text { 6th full- } \\
\text { time term }\end{array}$ & $\begin{array}{c}\text { 6th night } \\
\text { term }\end{array}$ & $\begin{array}{c}\text { 8th night } \\
\text { term }\end{array}$ \\
\hline $\begin{array}{l}\text { Number of nodes } \\
\text { Number of ties }\end{array}$ & 36 & 40 & 30 & 38 & 41 \\
Average ties per node & 270 & 342 & 228 & 476 & 352 \\
Degree of total centrality of the & 7,500 & 8,550 & 7,600 & 12,526 & 8,585 \\
network (degree) & 0,197 & 0,174 & 0,126 & 0,441 & 0,326 \\
Network density & 0,215 & 0,219 & 0,262 & 0,339 & 0,215 \\
Network diameter & 4 & 4 & 4 & 3 & 4 \\
Average geodesic distance & 2,102 & 2,191 & 1,995 & 1,694 & 2,091 \\
General clustering coefficient & 0,450 & 0,615 & 0,527 & 0,485 & 0,534 \\
\hline
\end{tabular}

Source: Research data

The network with the lowest number of students was the one in the 6th full-time period and the largest, in the 8th night term. The class with the highest number of relational ties and the highest average of ties per member was the 6th night term. Consequently, this class had a greater degree of total centrality, that is, a greater tendency to concentrate ties. It is also the group with the highest density, the smallest diameter and the shortest average geodesic distance (degrees of separation), that is, this is the group that revealed the greatest social cohesion in quantitative terms.

General clustering coefficient is the average of the coefficient of clustering of all the actors and allows to perceive the networks that are notoriously separated by structural holes (or areas of low density). This is the same as saying that networks with higher coefficients have greater separation between their subgroups. The 3 rd night term was the group with the highest coefficient, that is, it was the network that presented well-defined subgroups. The classes of the 3rd full-time term and 6th night term were those with the lowest coefficients and their subgroups are not so separated from each other.

\section{Subgroup analysis - modularity subgroups}

One of the challenges in SNA is to answer the question of how to detect subgroups (clusters) in a given social network. To this end, several algorithms have been developed. The most immediate way to detect subgroups, since it considers only the groups of complete density, is that of cliques. They would be the subgroups in which all members have relations with all the others (complete reciprocity). However, we understand that social groups do not always present strictly complete cohesion. A less restricted way to subdivide groups into social networks is to use some community detection algorithm. Therefore, in this study, we opted for the method proposed by Blondel, Guillaume, Lambiotte and Lefebvre (2008), available in the Gephi software, to subdivide the networks into subgroups of students with greater interaction with each other.

The networks shown in Figure 1 were segmented by the communities that are formed according to the density of relationships. The different shapes of the nodes disclose these communities (subgroups).

\section{Academic cohesion and performance}

More cohesive groups have a higher density of relationships. Next, in Table 3, we present the subgroups, their internal densities and their average academic achievements. 
Table 3 - Internal densities and Average PC of the subgroups

\begin{tabular}{|c|c|c|c|}
\hline Class & Subgroups & Internal density & Average $\mathrm{PC}$ \\
\hline \multirow{4}{*}{ 3rd full-time } & 1 & 0,4290 & 5,6737 \\
\hline & 2 & 0,8330 & 6,4429 \\
\hline & 3 & 0,7110 & 7,3315 \\
\hline & 4 & 0,6790 & 6,3204 \\
\hline \multirow{4}{*}{ 3rd night } & 1 & 1,0000 & 7,5511 \\
\hline & 2 & 0,4725 & 5,8721 \\
\hline & 3 & 1,0000 & 7,2476 \\
\hline & 4 & 0,7949 & 7,4916 \\
\hline \multirow{3}{*}{ 6th full-time } & 1 & 0,5303 & 6,7913 \\
\hline & 2 & 0,6889 & 7,6377 \\
\hline & 3 & 0,8214 & 8,1054 \\
\hline \multirow{4}{*}{ 6th night } & 1 & 0,6730 & 7,5558 \\
\hline & 2 & 0,5810 & 7,8191 \\
\hline & 3 & 0,8210 & 6,9114 \\
\hline & 4 & 1,0000 & 6,5106 \\
\hline \multirow{5}{*}{ 8th night } & 1 & 0,3182 & 6,4763 \\
\hline & 2 & 0,8571 & 8,0169 \\
\hline & 3 & 0,7385 & 7,6677 \\
\hline & 4 & 1,0000 & 7,4208 \\
\hline & 5 & 0,9333 & 7,5327 \\
\hline
\end{tabular}

Source: Research data

In order to verify the possible relation between social cohesion and academic performance, we proceeded to the analysis of linear regression between the internal density of the subgroups and the income coefficient. The result has shown a low coefficient of determination $\left(\mathrm{R}^{2}=0.223\right)$ for the variables, that is, the tendency for the more cohesive subgroups to perform better, in this work, is not significant. For example, this result contradicts in part Palacios et al. (2019), Lomi et al. (2011) and Carbonai (2017), for whom social relationships can influence academic performance.

The 3rd Night class was the one with the highest overall grouping coefficient. Therefore, it was the group that presented the best-defined subgroups, that is, the most cohesive subgroups and separated by structural holes. On the other hand, in the classes of the 3rd Integral and 6th Night classes, the subgroups were not so well separated; they are classes in which students are not grouped into "cliques".

\section{Bond formation by homophily - ERGM analysis}

By applying the models of random exponential graphs to the networks of this study, as described in the Methodology section of the research, it was possible to identify the individual attributes that contribute more sharply to the formation of bonds between the students of the classes.

The most satisfactory parameters for forming bonds between students in the classes analyzed are shown in Table 4. 
Table 4 - Chances of establishing links according to parameters (\%)

\begin{tabular}{lrrrrrrrrrr}
\hline Classes & Edges & Town & Cor & PC & Gender & Age & $\begin{array}{c}\text { In- } \\
\text { come }\end{array}$ & Residence & Job \\
\hline 3rd full- & 6,2 & 44,6 & 60 & 50,4 & $\mathbf{7 8 , 6}$ & 63,4 & 51,8 & 68,3 & 49,7 \\
time & & & & & & & & & \\
3rd night & 8,0 & 47,5 & 51,7 & 64,0 & $\mathbf{8 1 , 8}$ & 57,5 & 47,3 & 51,4 & 46,2 \\
6th full- & 21,9 & 48,5 & 51,9 & $\mathbf{5 8 , 0}$ & 53,8 & 39,9 & 56,1 & 49,3 & 52,0 \\
time & 16,3 & 58,5 & 52,7 & 55,5 & 57,9 & 51,3 & 56,3 & 51,4 & $\mathbf{6 2 , 7}$ \\
6th night & 8,2 & 51,5 & 50,1 & 63,7 & $\mathbf{6 8 , 1}$ & 43,9 & 44,7 & 60,5 & 60,5 \\
\hline 8th night & & & & & & & & & \\
\hline
\end{tabular}

Source: Research data

The attributes that were shown to exert greater strength to contribute to the generation of ties were: Gender; PC; Job.

Therefore, ERGM modeling has allowed us to arrive at the following answers: (1) the propensity to establish relationships between two students, regardless of any parameter, is small; (2) however, the chances increase when there is homophily among the actors. For three classes, the main factor that seems to influence the formation of bonds is gender, for one class, the coefficient of income PC and, for another class, whether they work or not.

According to the data presented in Table 4, the generation of relational ties between students is favored by homophilia, that is, by similarity in certain personal attributes. The analysis showed that the attributes that have the greatest influence were similarity by gender, according to Burk et al. (2007); Palacios and Berger (2015); Palacios and Villalobos (2016); followed by PC (performance) and work. This result, only a group in which the PC is more prevalent in forming bonds, partially contradicts Flashman (2012) and Lomi et al. (2011), who state that students with similar performances are more likely to form groups.

The results show that the relationships between students can be formed by visible attributes (gender and skin color) and not visible (age, PC and where they live) (Fortuin et al., 2016). Members in a network can initially be grouped by visible attributes, and over time, the links between them can become either strong or weak, due to the invisible attributes of each actor in the network.

As explained in Table 4, the 6th Night class was the only one that presented their chances of establishing numerically similar ties, with no significant difference between attributes, as in the other classes, which may indicate the presence of heterophilia in the formation of bonds (Carbonai, 2017). This can perhaps be explained by the high social cohesion that the class presents. This can be explained by the high social cohesion that the class presents.

It is necessary to emphasize the relationship between the data and the discipline. For example, there may be a difference in results between the discipline of Mathematics in Administration and People Management in Administration, in terms of forming networks. The results of this research show that there is no network standard for all classrooms, which can prove that different subjects can generate different results in the networks (Gremmen et al., 2017).

For a better understanding of the characteristics of the students' network of relationships, specifically in relation to their positioning in the network with academic performance, the social roles of these central actors in intersubgroup relations were analyzed.

\section{Intermediation between subgroups - Brokerage}

In this section we seek to identify the social roles that certain students play in the networks regarding brokerage between the subgroups. Intuitively, intermediation is the condition in which a network node acts as an intermediary between two others. Gould and Fernandez (1989) present 
five types of brokerage: Coordinator, Consultant, Gatekeeper, Representative and Liaison. Figure 2 illustrates this.

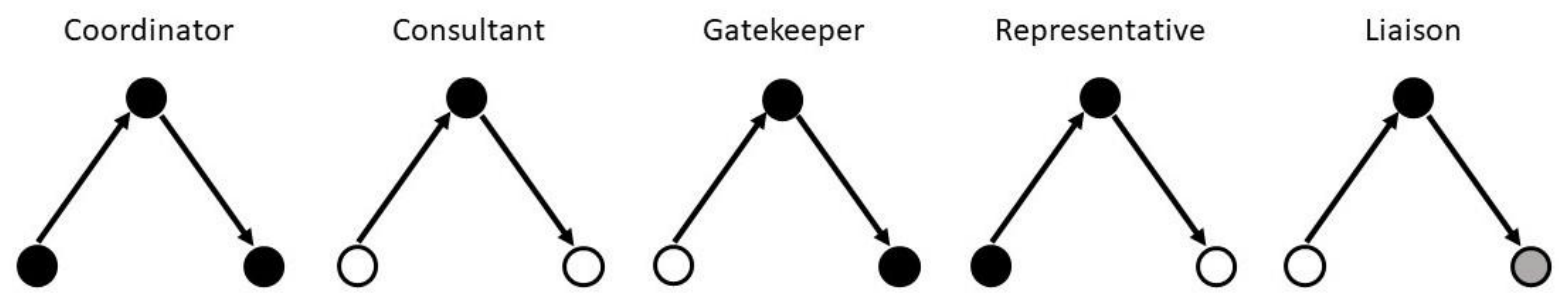

Figure 2 - Graphical representation of the five types of brokerage relationships

Note: Each node represents an actor and the lines between them represent their ties. The intermediate nodes are the brokers. The color differences of the nodes designate the affiliation subgroups.

Source: adapted from Gould and Fernandez (1989)

The gatekeeper receives the flow from other subgroups into its own subgroup. This provides the power to filter information that comes from outside, that is, in terms of relationships between students in a class, it can mean having privileged access to information. The gatekeeper can choose to retain this flow of information for him or herself, thereby gaining an advantage over other actors in the network.

For this reason, we chose to analyze the gatekeepers' performance, which are shown in Table 5.

Table 5 - Gatekeepers and subgroup performance

\begin{tabular}{|c|c|c|c|c|}
\hline Classes & Subgroups & $\begin{array}{c}\text { Main } \\
\text { Gatekeepers }\end{array}$ & $\begin{array}{c}\mathrm{PC} \\
\text { Gatekeepers }\end{array}$ & $\begin{array}{c}\text { Average } \\
\text { subgroup CP }\end{array}$ \\
\hline \multirow{4}{*}{ 3rd full-time } & 1 & $\mathrm{~A} 4$ & 7,16 & 5,67 \\
\hline & 2 & A 22 & 6,51 & 6,44 \\
\hline & 3 & A33 & 5,86 & 7,33 \\
\hline & 4 & A7 & 7,59 & 6,32 \\
\hline \multirow{4}{*}{ 3rd night } & 1 & A14 & 8,64 & 7,55 \\
\hline & 2 & $\mathrm{~A} 20$ & 6,5 & 5,87 \\
\hline & 3 & A5 & 7,64 & 7,25 \\
\hline & 4 & A19 & 8,09 & 7,49 \\
\hline \multirow{3}{*}{ 6th full-time } & 1 & $\mathrm{~A} 2$ & 7,31 & 6,79 \\
\hline & 2 & A5 & 7,02 & 7,64 \\
\hline & 3 & $\mathrm{~A} 24$ & 8,73 & 8,11 \\
\hline \multirow{4}{*}{ 6th night } & 1 & A12 & 7,16 & 7,56 \\
\hline & 2 & A31 & 9,36 & 7,82 \\
\hline & 3 & A11 & 7,11 & 6,91 \\
\hline & 4 & A35 & 7,27 & 6,51 \\
\hline \multirow{5}{*}{ 8th night } & 1 & A10 & 8,27 & 6,48 \\
\hline & 2 & A11 & 8,13 & 8,02 \\
\hline & 3 & A4 & 7,85 & 7,67 \\
\hline & 4 & A28 & 7,67 & 7,42 \\
\hline & 5 & $\mathrm{~A} 20$ & 7,59 & 7,53 \\
\hline
\end{tabular}

Source: Research data 
The position of intermediation between subgroups performed by certain students seems to have an impact on academic performance. Of the twenty students in gatekeeper positions, only three did not have a PC greater than the average of the subgroup to which they belonged (students A33 from the 3rd full-time, A5 from the 6th full-time and A12 from the 6th night).

Finally, in the data presented in Table 5, we highlight the position of intermediation between subgroups (brokerage). Students with intermediation positions between subgroups stood out in school performance. Most of the students identified as gatekeepers had higher performance than the average performance of students in the subgroups to which they belonged. This result indicates, using Saxena et al. (2019), a possible existing relationship between the intermediation role of the actors in the network and performance, as in the studies by Ortiz et al. (2004), which point out evidence in high school that the position in the network is associated with academic performance or even the studies by Liu et al. (2020), which point to superior performance as a characteristic of actors in central positions in student networks. Therefore, academic performance is a determining factor in the central position of the actors in the structures of the identified networks (Scott, 2000) Gatekeeper data indicate that superior performance can mean and be a consequence of privileged access to information coming from outside the subgroup.

Ultimately, it is concluded that the formation of bonds between groups can be answered by social selection within the classroom, where the individual's attributes matter for the formation of networks. The position the individual occupies in the network will influence their relationships and their academic performance, according to Scott (2000). The sense of community creates bonds between similar members and excludes non-similar members, creating cliques (closed groups), structural holes and bridges between subgroups.

However, there are considerations as to what influences, other than the attributes of peers, or networks, can lead to greater performance (Hanushek, Kain, Markman, \& Rivkin, 2003). Anyway, these authors have found that the performance of the peers positively affects the performance of the others. Furthermore, there are also studies that warn that the positive performance results of students, at the higher level, may have other influences than the peer effect, recommending caution when analyzing this effect on performance (Foster, 2006 ).

\section{Conclusion and final considerations}

This section presents the conclusion the final considerations of the work, which include research findings, work limitations, contributions to educational practice and future research. the limitations of the work, contributions to educational and teaching practice and future research.

The present work has investigated the structural characteristics of social relationships in the classroom of undergraduate courses in Administration at the Federal University of São João delRei (UFSJ). For that, the networks of relationships per classes have been identified, these networks have been analyzed from the cohesion per classes and the subgroups in the classes. The formation of cliques and the attributes that characterized the similarities between the actors per groups have also been analyzed. In addition, the relationship between subgroups and gatekeepers of each subgroup with academic performance was examined.

Among these results, we highlight as research findings, the clear identification of "cliques", especially in the 3rd night class, as shown in Table 2. Furthermore, this finding was associated with the performance of the subgroups, presenting a different result from that found in the literature researched, as the performance is not so well associated with the cohesion of the subgroups, but with students with superior performances situated in central positions, who receive the flow from other subgroups into their own subgroup. This gives them power in terms of relationships between students, which can mean privileged access to information. 
We also highlight the results of the homophily analyses, in which different factors were found among the different classes, with gender being predominant in the choice of who to study with. On the other hand, there is still that performance does not influence this selection, as only in the 6th full period class did the students make such a choice.

This work, however, presents some limitations. For example, the influence that peers can have on behavior or, more importantly, this influence on achieving academic performance, has not been analyzed. In addition, the peer selection process and what students consider for this selection has also not been analyzed.

As future research, it is possible to suggest investigations that consider the multidimensionality of homophily, according to Block and Grund (2014). In addition, longitudinal research can reveal changes in the network due to influence and selection, also considering impacts on academic performance. And yet, it is possible to evaluate the implications of the participation, to a greater or lesser degree, of students in networks or subgroups of these networks, in school permanence or dropout. According to Coulon (2017), there may not be an institutional affiliation process, with networks, or contacts, being fundamental to this affiliation process. In addition, qualitative research (Martinez, Dimitriadis, Rubia, Gómez, \& de la Fuente, 2003; Baggio, Scott, \& Cooper, 2010; Luthe \& Wyss, 2014) is suggested to obtain a deeper understanding of the object of analysis when using SNA.

Still in relation to qualitative research, it is proposed to analyze, in the students' social networks, how these groups collaborate, according to Palacios et al. (2019), with school involvement, permanence in higher education and the constraint of inappropriate behavior. Specifically in the academic field, according to Gibson (2003), social relations in these groups allow students to formulate thoughts and arguments with their peers.

Furthermore, it seems appropriate to suggest that similar research be carried out in private HEIs, and with distance learning groups (see, i.e., Fantinelli \& Russo, 2018). Depending on the profile of the students of private higher education institutions, it may be interesting to evaluate networks and subgroups according to attributes, mainly the socioeconomic level and skin color, different from those found in this researched public HEI. In the case of distance learning, to investigate whether distance and online interaction have any influence on the formation of groups and the choice of with whom to carry out academic tasks.

It is also suggested to carry out research in other higher education courses (engineering, medicine, for example), public and private HEIs, and in basic education (elementary and high school), as well as in public and private schools.

Still considering Coulon's argument (2017), research is recommended to obtain a greater understanding of the types of relationships that are developed among students and the results of these relationships in terms of commitment and persistence in remaining in undergraduate courses (Scott, 2000).

In the case of education in Brazil, it may be that there is some influence of our culture in the formation of groups and choice of peers. Thus, one can undertake comparative studies with other cultures. Furthermore, and considering the scarcity of research in this area in Brazil, regional culture can be an aspect that influences the formation of groups and the choice of peers. Thus, comparative studies between different Brazilian regions seem to be an important line of investigation.

This work is relevant for professionals involved in education, at the basic and higher levels, as it can offer an important tool to understand the dynamics of the classrooms and offer mechanisms of action so that students can improve their performance and seek solutions for themselves. avoid 
inappropriate behaviors, both in basic and higher education, according to Mamas, Daly, Struyve, Kaimi and Michail (2019).

According to van Rijsewijk, Oldenburg, Snijders, Dijkstra and Veenstra (2018), and the results of this research, the authors of this work recognize that the reality of teaching, namely the classroom, is a complex social system, and it is not possible to state that there is a typical classroom. Research on the nature of the one presented here can contribute to the challenge of making classrooms a social/academic environment that contributes to the growth in performance of all members of the class, helping in solutions for the exclusion of group members, low performance, abandonment of course/subjects, composition of groups and for a better performance of all students.

For example, when understanding the interactions that take place in the classroom, the teacher can encourage the formation of heterogeneous groups, by forming groups with a lower homophily index (by gender or performance, e.g.), in search of promoting interactions between groups or people (Mamas et al., 2019). With this, there may be a social "contagion", leading to an improvement in student performance (Gobithaasan et al., 2019; Leonardo et al., 2019; Fior, Mercuri, \& Almeida, 2011).

\section{References}

Andreoli, T. P., Leonardo, S. B., Farina, M. C., \& Lima, A. B. (2019, set-dez/2019). Redes formais e informais entre estudantes universitários: uma análise e comparação das estruturas gerais, similaridades e diferenças das redes, Gestão \& Regionalidade, 35(106).

Baggio, R., Scott, N., \& Cooper, C. (2010). Network science - A review focused on tourism. Annals of Tourism Research, 37(3), 802-827.

Bastian, M., Heymann, S., \& Jacomy, M. (2009). Gephi: An Open SourceSoftware for Exploring and Manipulating Networks. Proceedings of the Third International Conference on Weblogs and Social Media, ICWSM 2009, San Jose, Califórnia, EUA.

Block, P., \& Grund, T. (2014). Multidimensional homophily in friendship networks, Network Science, 2(2), 189-212.

Blondel, V. D., Guillaume, J-L, Lambiotte, R., \& Lefebvre, E. (2008). Fast unfolding of communities in large networks. Journal of Statistical Mechanics: Theory and Experiment, (10).

Borgatti, S. P., Everett, M. G., \& Freeman, L. C. (2002). Ucinet 6 For Windows - Software for Social Network. Analysis. Havard Analytic Technologies.

Burk, W. J., Steglich, C. E. G., \& Snijders, T. A. B. (2007). Beyond dyadic interdependence: Actororiented models for co-evolving social networks and individual behaviors. International Journal of Behavioral Development, 31(4), 397-404.

Burke, M. A., \& Sass, T. R. (2020). Classroom Peer Effects and Student Achievement [Working paper 18]. Recuperado em 20 julho, 2020 de https://www.urban.org/sites/default/files/publication/33186/1001190-Classroom-Peer-

Effects-and-Student-Achievement.PDF

Carbonai, D. (2017). Integração e relações étnico-raciais. Um exercício de análise de redes sociais, RIAEE - Revista Ibero-Americana de Estudos em Educação, 12(1), 215-227.

Carbonai, D., \& Colvero, R. B. (2014). Papéis sociais no ensino médio: uma análise baseada na teoria das redes. Revista Brasileira de Educação, 19(58), 671-689.

Carneiro, A. S. C. (2010). Caminhos universitários: a permanência de estudantes de origem popular em cursos de alto prestígio. Dissertação de mestrado, - Universidade Federal da Bahia, Salvador, BA, Brasil.

Cohen, J. M. (1977). Sources of peer group homogeneity, Sociology of Education, 50(4), 227-241. 
Coleman, J. S., Campbell, E. Q., Hobson, C. J., McPartland, F., Mood, A. M., Weinfeld, G. D., \& York. R. L. (1966). Equality of Educational Opportunity. Washington, DC: U.S. Government Printing Office. Recuperado em 10 junho, 2019, de https://files.eric.ed.gov/fulltext/ED012275.pdf

Coulon, A. (2008). A Condição de Estudante: A Entrada na Vida Universitária (Introdução, p. 31-45). Salvador-BA: Edufba.

Coulon, A. (2017, outubro/dezembro). O ofício de estudante: A entrada na vida universitária, Educação e Pesquisa, 43(4), 1239-1250.

Dawson, S. (2008). A study of the relationship between student social networks and sense of community. Educational Technology \& Society, 11(3), 224-238.

de Klepper, M., Sleebos, E., van de Bunt, G., \& Agneessens, (2010). F. Similarity in friendship networks: Selection or influence? The effect of constraining contexts and non-visible individual attributes. Social Networks, 32, 82-90.

Fantinelli, S., \& Russo, V. (2018). Community of practice online - the importance of technology for learning: an application of social network analysis, Journal of e-Learning and Knowledge Society, 14(3), 29-39.

Fernandes, J. H. C., Maranhão, J. P. A., de Andrade, C. A. B., \& Sampaio, R. B. (2017, julho). Uma análise da colaboração científica numa área da pós-graduação brasileira por meio da modelagem estatística de redes sociais usando ERGM: Estudo de caso. In: Brazilian Workshop On Social Network Analysis And Mining (BRASNAM). Anais do VI Brazilian Workshop on Social Network Analysis and Mining. Porto Alegre: Sociedade Brasileira de Computação. Recuperado em 25 março, 2020, de https://sol.sbc.org.br/index.php/brasnam/article/view/3256/3218

Fior, C. A., Mercuri, E., \& Almeida, L. S. (2011). Escala de Interação com Pares: construção e evidências de validade para estudantes do ensino superior, Psico-USF, 16(1), 11-21.

Flashman, J. (2012). Academic achievement and its impact on friend dynamics. Sociology of Education, 85(1), 61-80.

Fortuin, J., van Geel, M., \& Vedder, P. (2016). Peers and academic achievement: A longitudinal study on selection and socialization effects of in-class friends, The Journal of Educational Research, 109(1), 1-16.

Foster, G. (2006). It's not your peers, and it's not your friends: Some progress toward understanding the educational peer effect mechanism, Journal of Public Economics, 90(8-9), 1455-1475.

Gibson, S. (2003). Narrative of a pre-service teacher. English Teaching: Practice and Critique, 2(3), 3546.

Gobithaasan, R. U., Din, N. S., Amachandran, L., \& HASNI, R. (2020). Boosting students performance with the aid of social network analysis. Recuperado em 10 abril, 2020, de https://arxiv.org/abs/1906.04352

Gould, R., \& Fernandez, R. (1989). Structures of mediation: A Formal Approach to Brokerage in Transaction Network, Sociological Methodology, 19, (89-126). doi:10.2307/270949

Gremmen, M. C., Dijkstra, J. K., Steglich, C., \& Veenstra, R. (2017). First selection, then influence: Developmental differences in friendship dynamics regarding academic achievement, Developmental Psychology, 53(7), 1356-1370.

Handcock, M. S., Hunter, D. R., Butts, C, T., Goodreau, S. M., \& Morris, M. (2003). Statnet: Software tools for the Statistical Modeling of Network Data. Seattle-IWA, EUA. Recuperado em 01 julho, 2020, de http://statnet.org/

Hanushek, E. A., Kain, J. F., Markman, J. M., \& Rivkin, S. G. (2003). Does peer ability affect student achievement? Journal of Applied Econometrics, 18, 527-544.

Hong, S. C., \& Lee, J. (2019). Who is sitting next to you? Peer effects inside the classroom, Quantitative Economics, 8(1), 239-275. 
Leonardo, S. B., Farina, C., Andreoli, T. P., \& Lima, A. P. M. B. de (2019). Relacionamentos Interpessoas Formal e Informal: Interação das Redes no Ambiente Acadêmico, RAC - Revista de Administração Contemporânea, 23 (3), 395-415.

Liu, Z., Kang, L., Su, Z., Liu, S., \& Sun, J. (2020). Investigate the relationship between learners social characteristics and academic achievements Journal of Physics: Conference Series. 1113 012021, v 1113, 5th International Workshop on Statistical Physics and Mathematics for Complex Systems (SPMCS2017) 12-15 October 2017, Wuhan, China. Recuperado em 10 abril, 2020, de https://iopscience.iop.org/article/10.1088/1742-6596/1113/1/012021

Lomi, A., Snijders, T. A. B., Steglich, C. E. G., \& Torló, V. J. (2011). Why are some more peer than others? Evidence from a longitudinal study of social networks and individual academic performance. Social Science Research, 40, 1506-1520.

Luthe, T., \& Wyss, R. (2014). Assessing and planning resilience in tourism, Tourism Management, 44, 161-163.

Mamas, C., Daly, A. J. Struyve, C., Kaimi, I., \& Michail, G. (2019). Learning, friendship and social contexts - Introducing a social network analysis toolkit for socially responsive classrooms, International Journal of Educational Management, 33(6), 1255-1270.

Martinez, A., Dimitriadis, Y., Rubia, B., Gómez, E., \& de la Fuente, E. (2003). Combining qualitative evaluation and social network analysis for the study of classroom social interactions, Computers \& Education, 41, 353-368.

Ortiz, M. G. R., Hoyos, J. R. C., \& López, M. G. R. (2004). The social networks of academic performance in a student context of poverty in Mexico, Social Networks, 26(2), 175-188.

Palacios, D. Dijkstra, J. K., Villalobos, C., Treviño, E., Berger, C., Huisman, M., \& Veenstra, R. (2019). Classroom ability composition and the role of academic performance and school misconduct in the formation of academic and friendship networks, Journal of School Psychology, 74, 58-73.

Palacios, D., \& Berger, C. (2015). ¿Son los buenos estudiantes amigos deseables? Evidencia para la selección de amistad entre estudiantes de educación primaria, Estudios de Psicología, 36(2), 496-508. Palacios, D., \& Villalobos, C. (2016). Redes académicas al interior de las escuelas chilenas: Un estudio exploratorio utilizando Modelos Exponenciales de Grafos Aleatorios (ERGM), Revista Hispana para el Análisis de Redes Sociales, 27(2), 33-44.

Portes, E. A. (2014). A vida universitária de estudantes pobres na UFMG: possibilidades e limites. In: D. C Piotto. (Org.), Camadas populares e universidades públicas, São Carlos, SP: Pedro \& João Editores.

Rovai, A. P. (2002). Development of an instrument to measure classroom community. Internet and Higher Education, 5(3), 197-211.

Sacerdote, B. I. (2001). Peer effects with random assignment: results for Dartmouth roommates, Quarterly Journal of Economics, 116(2), 681-704.

Sampaio, S. M. R., \& Santos, G. G. dos. (2015). Ateoria da afiliação: notas para pensar a adaptação de novos públicos ao ensino superior, Atos de Pesquisa em Educaşão, 10(1), 202-214.

Santos, A. S., Oliveira, C. T., \& Dias, A. C. G. (2015). Características das relações dos universitários e seus pares: implicações na adaptação acadêmica, Revista Psicologia: Teoria e Prática, 17(1), 150-163.

Saxena, A., Reddy, H., Saxena, P., \& Gera, R. (2020). A Survey on Studying the Social Networks of Students. Recuperado em 10 abril, 2020, de

https://arxiv.org/search/?query=A+Survey+on+Studying + the + Social + Networks + of + Students \&searchtype $=$ title

Scott, T. L. (2000). Ties That Bind: A Social Network Approach to Understanding Student Integration and Persistence. The Journal of Higher Education, 71(5), 591-615. doi:

$\underline{10.2307 / 2649261}$ 
Shin, H., \& Ryan, A. M. (2014). Early adolescent friendships and academic adjustment: examining selection and influence processes with longitudinal social network analysis. Developmental Psychology, 50(11), 2462-2472.

Smirnov, I., \& Thurner, S. (2016). Formation of homophily in academic performance: students prefer to change their friends rather than performance, Plos One, 12(8).

Smith, M. (1944). Some Factors in Friendship Selections of High School Students, Sociometry, 7(3), 303-310.

Snijders, T. A. B., \& Baerveldt, C. (2003). A multilevel network study of the effects of delinquent behavior on friendship evolution, The Journal of Mathematical Sociology, 27(2-3), 123-151. doi: 10.1080/00222500305892.

Teixeira, M A. P, Dias, A. C. G., Wottrich, A. B., \& Oliveira, A. M. (2008). Adaptação à universidade em jovens calouros adaptação à universidade, Revista Semestral da Associação Brasileira de Psicologia Escolar e Educacional (ABRAPEE), 12(1), 185-202.

Teixeira, M. A. P., Castro, A. K. S. S., \& Zoltowski, A. P. C. (2012). Integração acadêmica e integração social nas primeiras semanas da universidade: percepções de estudantes universitários. Gerais: Revista Interinstitucional de Psicologia, 5(1), 69-85.

Tinto, V. (1997). Classrooms as Communities, The Journal of Higher Education, 68(6), 599-623.

Tinto, V. (1975). Dropout from Higher Education: A Theoretical Synthesis of Recent Research, Review of Educational Research, 45(1), 89-125.

Van de Bunt, G. G., van Duijn, M. A. J., \& Snijders, T. A. B. (1999). Friendship networks through time: an actor-oriented dynamic statistical network model, Computational and Mathematical Organization Theory, 5, 167-192.

Van Rijsewijk, L. G. M., Oldenburg, B., Snijders, T. A. B., Dijkstra, J. K., \& Veenstra, R. (2018). A description of classroom help networks, individual network position, and their associations with academic achievement, PLoS ONE, 12(13), 1-22. Recuperado em 20 julho, 2020, de https://journals.plos.org/plosone/article?id=10.1371/journal.pone.0208173

Wentzel, K. R. (2010). Battle, A., Russell, S. L., \&Looney, L. B. (2010). Social supports from teachers and peers as predictors of academic and social motivation, Contemporary Educational Psychology, 35, 193-202. 